\title{
Air Democracy: on the Principles of Breathing Together
}

\section{Aleksander Kopka ${ }^{1}[$}

Accepted: 12 January 2022 / Published online: 2 March 2022

(c) The Author(s) 2022

\section{There remains air...}

(Irigaray, 1999: p. 13).

\section{Breathing Together}

In her prominent work The Forgetting of Air in Martin Heidegger, Luce Irigaray writes:

Is not air the whole of our habitation as mortals? Is there a dwelling more vast, more spacious, or even more generally peaceful than that of air? Can man live elsewhere than in air? [...] No other element is as light, as free, and as much in the "fundamental" mode of a permanent, available, "there is." (Irigaray, 1999: p. 8).

Adding a couple of pages further:

Air would be the arch-mediation: of the logos, of thinking, of the world whether physical or psychical. Air would be the substance of the copula that would permit the gathering-together [le rassemblement] and the arrangement of the whole into the life and Being of man, and permit his habitation in space as a mortal. But this arche-ness would never be able to be constituted as an origin because of its mediating qualities and because it is a permanent necessity for the immediate subsistence of man. (p. 12).

These short passages encapsulate Irigaray's reasoning behind her conviction about the profound role of air as the ultimate dwelling place and the very condition of life. However, they can also be treated as an outline for the political problematics that stem from the statement about air as an anarchic medium in which ethical and

This paper builds upon my research on the notions of "democracy" and "sharing out" presented in 'Sharing (Out) Democracy. On the Democratic Injunction for Climate Justice' (Kopka, 2020) and in some regard continues its line of argument.

Aleksander Kopka

olekkopka@gmail.com

1 Institute of Philosophy, University of Silesia in Katowice, Katowice, Poland 
social relations can emerge. As something that cannot be 'constituted as an origin,' air does not surrender itself to onto-theological submission. In her polemics with Heidegger, where she tries 'to re-discover the possibility of a relation to air' (p. 29), Irigaray argues that throughout the history of metaphysics, and in our phallocratic culture, this originary constituent of everything that lives has been forgotten. The neglect of air, particularly its materiality (which has been reduced to nothingness by philosophy possessed with logos), creates a vacuum of knowledge and perception. Simultaneously, air, which is the opening, the condition of possibility for every intelligible operation, remains unthought (p. 2), both because it is not of any concern for logos focused on static representation and because air simply eludes this kind of thinking based on appropriation and possessive knowledge. As Irigaray puts it, '[a]lways there, [air] allows itself to be forgotten' (8). In her critique of this philosophical ignorance, she mocks Plato and his paternalistic concept of the intelligible sun, stating that 'oblivion is of the sun' and that '[1]ight permits approximation of "things" at a distance. It permits "things" to come to him [Irigaray surely addresses here not only Heidegger but also a long tradition of male-philosophers - A.K.], and to each other, in a (non-)distancing that is more or less remote' (p. 43). The forgetting of air means that man is torn from his natural belonging; he deprives himself of a more authentic relation to what is necessary for his existence. In his pursuit of immortality in knowledge, in his attempt to be the master of the universe, man therefore risks losing his life (p. 13), since he deprives it of air: 'Man, wanting to regain possession of himself as constituting and gathering together the whole, apprehends only the nothing: a fabricated air-bubble, empty correlate of the whole' (p. 17).

The petrification of living matter through its conceptualization, the 'uncontrolled exploitation of air by language and by systems of representation' (p. 10) is challenged by Irigaray with the introduction of the question of relationality, which destabilizes the philosophical domain mastered by logos. Air's role here is crucial for it is the material mediation (which eludes the binary division between intelligible and sensible), an originary milieu where two different worlds and two different living singularities meet each other. Thus, the materiality of air necessarily coincides with the process of incessant differentiation (Szopa, 2018: p. 337): 'Air and sexual difference may be the two dimensions vital for/to life' (Irigaray, 1996: p. 37). Irigaray's thought therefore confronts a tradition that: on the one hand, forgot both how to breath and that breathing is the first autonomous gesture of living human being (Irigaray, 2004b: p. 165; Irigaray, 2015: p. 253); and on the other, it 'does not recognize the existence of two different subjects and does not care enough about ethics regarding their relations' (Irigaray, 2015: p. 253). Therefore, Irigaray bluntly asks: 'Without air, is place livable for a mortal?' (Irigaray, 1999: p. 20).

In contrast to the phantasmatic idea of fully erected life, Irigaray states that this kind of upright self-positioning, characteristic of masculine individualization, results in separation from the environment and misappreciation of air as what supports us in living (p. 14). This attitude, which Irigaray denounces as artificial, deprived of air, forgetful, and even suicidal, inevitably leads to misapprehension and deterioration of nature.

A breaking-in, a clearing of land, and a cultivation of this cleared land in order to take root in the natural world, to take from it the wherewithal to ensure his 
subsistence, to draw from it the means to feed his erecting. [...] But doesn't this exploitation of nature by man run the risk of leading to his own death? (p. $18)$.

It is not hard to imagine how this logocentric purification and petrification of life can serve as an excuse or incentive to environmental cleansing, such as profit-driven deforestation or extraction of natural resources. One could therefore argue that The Forgetting of Air..., first published in 1983, is a philosophical canary in a coal mine: not only is it an announcement of the climate catastrophe we have been heading towards but also a text that provides us with a diagnosis and theoretical tools to at least address this issue in a systematic way (by linking the attitude that drives the environmental crisis with the exploitation and debasement of women in the Western tradition). Thus, it seems that for Irigaray, the most urgent issue of the present time is both the disregard for sexuate difference and the fact that because of our immersion in the insensate and exploitative culture, 'we breathe poorly' (Irigaray, 2015: p. 254).

The realization about the importance of breathing cannot however take place without 'opening a space for woman's subjectivity by reconnecting nature with spirit and culture' (Škof, Holmes, 2013: p. 2) and taking into account the significance of sharing air, which for Irigaray is 'above all a common good, shared by different worlds and different singularities' (Szopa, 2018: p. 338). Moreover, the role of woman, as the original gift-giver, in this aerial emancipation, which transgresses the boundaries of the economy of growth and goes even beyond reciprocity, has to be emphasized. As she argues, "[t]he first relation with the other that woman knows is based on respect for life and the sharing of life' and her breath 'remains in her in order to be shared, to become fertilized' (Irigaray, 2015: p. 255).

She gives - first - air, and does so irrecoverably, with the exception of the unfolding, from and within her, of whoever takes air from her. While this air is - first - fluid matter carried by the blood she gives, it can also be understood as voice and phenomenon. ${ }^{1}$ These issue from it and are the possibility - ever material - of naming-denominating, of appearing in presence.

She gives first. She gives the possibility of that beginning from which the whole of man will be constituted. This gift is received with no possibility of a return. (Irigaray, 1999: p. 28).

Although the relationality Irigaray is interested in begins with man's bond to the mother's body, it cannot end there, for it has to lead to what I propose to call a relational autonomy since for her the other is 'the one who is needed for us to become ourselves' (Irigaray, 2019: p. 3) and this autonomy cannot take place unless we realize that only our co-belonging with the other can elevate us 'to a transcendental level' (p. 68). However, our development that takes place specifically in relation to

\footnotetext{
1 Aside from being probably an allusion to Derrida's early text Voice and Phenomenon, in which he undertakes deconstruction of transcendental autonomy in Husserl's project of phenomenology, this sentence might be considered a strong insistence on the irreducibility of material, relational genesis in every transcendental approach to institute an autonomous subject.
} 
'the transcendent other' (p. 4) may happen only through preservation of our breath and cultivation of our breathing.

This autonomy consists in its first gesture, namely, to breathe independently of prenatal passivity. Moreover, the injunction Irigaray attests to has to revolve around the idea of incalculable sharing, of which sharing of air is the exemplar. Furthermore, these two words used by Irigaray, 'fertilization' and 'sharing,' are not just a rhetorical ornament - they are crucial to understanding her political stance, which finds its source of inspiration in the natural world. As she argues, it is the world of plants that distributes air (as the most profound means of support to all living organisms) in the most democratic way, and that makes our transition from placental dependency to the reality of living together (with other organisms) as breathing together possible ( $c f$. Szopa, 2018: p. 340). This approach also necessitates a rethinking of what 'together' might mean. In Ethical Gestures Towards the Other, Irigaray explains:

"Together", then, no longer means participating in a common world that is already there and imposed on the two. "Together" now implies that each one has to discover and assume a world of one's own, and that each one agrees to venture beyond one's world in order to open up to the world of the other and build a shared world with respect for the difference(s) between one another. Such a world in part remains always future and transcendent to each one, it can be appropriated by none. In the construction of this shared world the one and the other affirm their singularity and their freedom while risking them to the other. (Irigaray, 2015: p. 258).

Togetherness thus is not something that can be preestablished, and just as there is no fixed commonality of the world, there is also no fixed pattern or prescription for our living together other than the one inspired by our natural belonging (which is anything but simple or homogeneous). The idea of sharing has therefore to denote the futility of theoretical ambitions to immobilize and master the world, and at the same time, it has to imply a task or a challenge, which is both ethical and political, to engage ourselves in construction and transformation of this shared world. It cannot however take place without respect for air as the matter that renders this 'gathering-together' possible. For Irigaray, that means an effort without which there would be no democracy: to 'free the two from the one,' and consequently, 'the other from the same' (Irigaray, 2000: p. 129). She even mentions that '[w]ithout such a gesture philosophy itself risks suffocating' (p. 130). Democracy as a political intention to coexist responsibly with other living beings in recognition of their insurmountable alterity has to imply 'a willingness to respect nature, the other, others' (p. 8). As such, it has to revolve around the cultivation of breath and respect of sexuate difference. Thus, I argue that there is an essential political importance and urgency in Irigaray's philosophy of air and breathing that should inspire our reflection on the current state of democracy and its future. In effort to do that, the radical potential of these writings to think the future outside of the rigid limits of philosophical economies and political dogmas has to be brought to the fore. Perhaps democracy, just like air, escapes any final determination and thus leaves the question of our living together always open. Nevertheless, if it aims to be the answer to our struggles with 
the culture of alienation and exploitation, it has to involve a thorough critique of the mechanisms of political, economic and cultural dominance.

\section{Air Democracy}

From this point of view, Irigaray's thought of sexuate difference can surely be accompanied by Jacques Derrida's reflection on the unfulfilled and even impossible ideal of democracy. Now, while 'Derrida also thinks through sexual difference,' as Lenart Škof rightly points out, 'it is Irigaray who bases her entire philosophy on it: from ontology to ethics as well as, in her later period, the ethics of breath' (Škof, 2015: p. 140). It seems quite intriguing how the question of democracy brings these two thinkers together, especially in the case of addressing the problem of phallocratic dominance within the political realm. The deconstruction of phallocratic models of sovereign power (or even phallocentric presuppositions in the very idea of sovereign power) that Derrida carries out could enrich, and strengthen, as I believe, Irigaray's standpoint precisely because of the responsiveness of his thought to the question of sexuate difference. $^{2}$

This sensibility can be found, for example, in Rogues, where Derrida traces the androcentric genealogy of democracy based on 'a principle of legitimate sovereignty, the accredited or recognized supremacy of a power or a force, a kratos or a cracy' (Derrida, 2005: p. 12). As he states, the fraternalistic take on democracy consists in 'the egalitarian contract established between rival sons and brothers, in the succession of the father, for the sharing of kratos and the demos' (17). As such, democracy would be a revival of political theology based on the transfer of power between father, son and brother, which would make democracy 'phallocentric, phallo-paterno-filio-fraterno-ipsocentric' (17). Consequently, Derrida emphasizes the theological origin of ipsocratic authority bequeathed first to the monarch and later to the people: 'Sovereignty was then delegated to the people, in the form of democracy, or to the nation, with the same theological attributes as those attributed to the king and to God' (Derrida, Roudinesco, 2004: pp. 91-92). For Derrida, this concept of democratic sovereignty is, of course, untenable since it does not address the question of the infinitely other but instead focuses on the value of ipseity (which revolves around being properly oneself as 'the sovereign and reappropriating gathering of the self' [Derrida, 2005: p. 11]), and therefore, it is concerned vastly more with what (or who) is similar or semblable than with the other. ${ }^{3}$ While the

\footnotetext{
2 In my view, one of the most important — if not the most important — aspects of Irigaray's and Derrida's shared respect for difference is their protest against objectification, assimilation, appropriation, or thematization of the other (in other words, their resistance against what Emmanuel Levinas would call 'the imperialism of the same'). For Irigaray, turning the other into an object is 'a sort of murder of the other, either by overtly killing him or her or, more indirectly, by depriving them of their breathing, of their life' (Irigaray, 2019: p. 17).

3 Moreover, following Émile Benveniste, Derrida refers to the etymological background of ipseity. The latter consists not only in its self-centered potency or power, but is also connected to property, possession, and mastery in the way in which ipse 'designates the oneself as master in the masculine: the father, husband, son, or brother, the proprietor, owner, or seignior, indeed the sovereign' (Derrida, 2005: p. 12).
} 
ipsocentric democracy cannot be thought without resorting to symmetry, semblance, kinship, homogeneity, and even God, there is another, antithetic 'truth of the democratic' that does not cave in under the sovereign reign: 'the truth of the other, heterogeneity, the heteronomic and the dissymmetric, disseminal multiplicity, the anonymous "anyone," the "no matter who," the indeterminate "each one" (Derrida, 2005: pp. 14-15). According to Derrida, democracy has to embrace the truth based on the address toward the other should the political future remain open, which means that we have to think about the possibility of the at-home-with-oneself or any social bond on the basis of this interruption or the unbinding (namely, an originary, quasiontological challenge to any preestablished bond that consists in the view that every bond [liaison] is possible solely on condition of its impossibility, i.e., its unbinding [déliaison]) as an always unique address toward the singular other. In his words of adieu to Emmanuel Levinas, Derrida writes that ' $[\mathrm{t}] \mathrm{he}$ at-home-with-oneself of the dwelling does not imply a closing off, but rather the place of Desire toward the transcendence of the other. [...] The social bond is a certain experience of the unbinding without which no respiration, no spiritual inspiration, would be possible. Recollection, indeed being-together itself, presupposes infinite separation' (Derrida, 1999: p. 92).

Furthermore, in Faith and Knowledge, he states that '[t]here is no opposition, fundamentally, between "social bond" and "social unraveling." A certain interruptive unraveling is the condition of the "social bond," the very respiration of all "community", (Derrida, 2002: p. 99). Perhaps this respiratory metaphor attesting to the political openness and affirmation of alterity as the condition of living together is not accidental here and Derrida's diagnosis is very close to Irigaray's democratic protest against totalization and appropriation of the other - which is also an invitation to more rational and respectful thinking about our living together - since '[c] reating an opening in the horizon of a personal or collective world puts the limits of this world into perspective' (Irigaray, 2015: p. 257).

While for Derrida the democratic ideal is essentially aporetic and the coming of a just democracy has to remain interminably deferred, Irigaray reaches to the Greek tradition of democracy, which she interprets as the process of individualization of human beings: '[t]o take up again the task of individualization at work in Greek democracy seems at once a work of justice in accordance with the democratic ideal and a means of saving democracy itself, in particular from all the forms of totalitarianism that threaten it' (Irigaray, 2011: p. 199). Of course, as she argues, this cannot take place without respect for sexuate difference because the latter is 'the most radical difference and the most necessary to the life and culture of the human species' (Irigaray, 1992: p. 3). As such, it is indispensable in 'achieving civil coexistence between other forms of difference' (Irigaray, 2000: p. 12) because respect of the difference between man and woman leads not only to recognition of their singular autonomy and dignity, their desires and respective rights, but overall to a concern about difference and thus to 'the recognition of other forms of diversity' (12).

Irigaray's emphasis on sexuate difference is also something that unavoidably troubles androcentric sovereignty and its raison d'être, which immobilizes the other in 
a homogeneous knowledge. ${ }^{4}$ Thus, in a similar vein to Derrida's critique of phallocratic sovereignty, Irigaray denounces androcentrism and masculinization of democracy. However, in her case, the first other she is concerned with is woman, for there is no chance for a fully democratic society as long as woman 'is subjected to a loss of identity which turns love into duty, a pathology, an alienation for her' (Irigaray, 1992: p. 2), and therefore as long as we choose to cultivate the same over the affirmation of difference: '[t]his means that [woman] should not be subordinated first to her father, her uncle or her brother, then to her husband's line, nor to the values of a masculine identity, whether these be social, economic or cultural' (3). Consequently, we have to challenge hierarchical transcendence and filial genealogy in favor of horizontal transcendental difference between the sexes, which facilitates the cultivation of desire between the two and 'creates space, spaces, whereas reducing it to a genealogy destroys them or fills them up' (Irigaray, 2004a: p. 132). ${ }^{5}$ Irigaray states that we have to overcome 'the dependence on genealogy' (Irigaray, 2004b: p. 169) and thus question our reliance on the theogonic, paternalistic model of governance. That is why she professes that divinity should not be regarded in terms of some hierarchical order but something humans should aspire to: 'God is us, we are divine if we are woman and man in a perfect way' (p. 169). As Roland J. de Vries explains, '[t]his god in the feminine will not reflect the idealized human subject of Western philosophy and history - a God as a foundation for Certainty and Truth' (De Vries, 2008: p. 146). Therefore, the divinity Irigaray has in mind has to break with the whole of political tradition rooted in masculine filiality; it has to involve a renouncement of

\footnotetext{
${ }^{4}$ What is also symptomatic in the context of sovereignty is Irigaray's staunch objection to the death penalty. Capital punishment is one of the most striking examples of contradiction between unconditional respect for life (which for her is the primary concern of democracy) and the policy of nation-states which 'present themselves as models of democracy' (Irigaray, 2011: p. 198). Yet, they grant themselves the right to take a life. That, of course, can be treated as a vindication of a sovereign political power, which, according to Derrida, '[...] signals its sovereignty, its sovereign right over souls and bodies, and which in truth defines its sovereignty by this right and by this power: over the life and death of subjects. That is how the essence of sovereign power, as political but first of all theologico-political power, presents itself, represents itself as the right to decree and to execute a death penalty. Or to pardon arbitrarily, sovereignly' (Derrida, 2014: p. 22).

${ }^{5}$ Irigaray accentuates the importance of creating a 'non-hierarchical loving relationship between the sexes' (Irigaray, 1992: p. 4) that has to arise from sexuate difference since only through the latter can one awake desire for the other and approach the other as a transcendence while remaining in oneself (Irigaray, 2015: p. 266). While in Sharing the Fire Irigaray states that it is 'the respect for another living being as different' that opens the transcendental horizon, she concurrently argues that it is precisely the role of desire, which acts 'in a simply natural motion, through relating to the other as naturally different' (Irigaray, 2019: p. 4). However, the notion of desire cannot be reduced to a mere natural need but it also implies spiritual growth, since it reconciles the natural and the spiritual sphere of our life. As such, it has a special place in Irigaray's philosophy that hinges on breathing. Irigaray even argues that woman's ability to awaken desire seems to result from her 'greater reserve of breath' (Irigaray, 2015: p. 254). As Szopa evidences, desire in Irigaray's view is '[...] shared with the other(s), which implies that it acts as a double force: empowering new manifestations of being and building a world as a place of peaceful coexistence between all living beings. Thus, the ethical responsibility of two different beings will ask for the constant development and blossoming of themselves and their relation with one another. This undertaking is based on the respect for otherness and represents an essential work of mediation between an individual and community' (Szopa, 2019: p. 67, $c f$. Irigaray, 2016: p. 95). That is why for Irigaray sharing desire with the other is 'the origin and the end of a human becoming' (Irigaray, 2019: p. 2).
} 
'genealogical behavior,' which 'somehow implying hierarchy, still avoids a meeting with the other, whom we have to recognize horizontally as equivalent to us in the radical respect for his, or her, difference(s)' (Irigaray, 2015: p. 266).

The horizontal transcendence, 'an incarnate transcendence' (Irigaray, 2019: p. 4) — and, by the same token, 'horizontal efflorescence' (Irigaray, 1999: p. 106) ${ }^{6}$ — is however impossible to achieve until we overcome the masculine individualization, which takes place by means of separation rather than differentiation from the other. Through this detachment and alienation, the masculine individualization doubles down on 'a relation between those who were the same, whose difference was only quantitative, or, one could also say, competitive' (Irigaray, 2011: p. 195). Hence, 'a democracy established by and for men alone must be governed in the neuter' ( $\mathrm{p}$. 195), and as such, it is obsessed with quantifiable competition and conquest rather than focused on respect for qualitative differences. This diagnosis leads Irigaray to a conclusion that democratic politics has been obscenely measurable and that ' $\mathrm{t}$ ] he law that rules our societies is concerned, above all, with property, possessions, and goods' (p. 197). However, precisely out of concern for sexuate difference, a new ethical 'way of behaving politically' may emerge: 'In place of an era of domination, production, exploitation, there could come into being an era of coexistence, awareness of limits, and respect for natural and cultural riches' (Irigaray, 2000: p. 13). Therefore, if we want to build a democratic society, we cannot treat neutrality as the determinant of our relationships because, as Irigaray stresses, societies are created by individuals who 'are linked together, particularly through sexed relationships' (p. 118). That is why Irigaray proposes a renewal of the foundations of democracy on the basis of 'a just relationship between two beings' (p. 118), which she considers a remedy for the destructiveness of 'our cultural and social habits founded on self-identity - the proper, the similar, the same, the equal, etc. [...]' (Irigaray, 2015: p. 266), of reducing otherness to sameness and treating human beings as neutral monads.

By emphasizing the importance of respecting sexuate difference, Irigaray urges us to rethink the role and status of women in democratic societies in the spirit of feminized humanism. The latter takes the form of an unequivocal rebuke of 'a supposedly neutral and universal culture' (Irigaray, 2011: p. 202) as a culture that, through the erasure of gender and exclusion of women, excludes the very human being since it deprives humans not only of conditions for their very survival but also the possibilities to flourish and coexist in a respectful manner. Thus, the first task of democracy should consist in treating women as autonomous citizens capable of taking responsibility for themselves and for the society they constitute. Women cannot be reduced to their natural functions or their social status assigned under the phallocratic order. Instead, they must attain their 'civic identity' that has to embrace 'a pedagogy of respect for a difference between individuals' (p. 201). Hence, as Irigaray postulates, 'legislation today must start again from the person's right to exist

\footnotetext{
${ }^{6}$ Cf. Szopa, 2018: p. 341. In Poetyka rozkwitania..., Szopa devotes a whole chapter to the question of vegetation in Irigaray's philosophy and concludes it with reflections on the 'rhythm of breath'.
} 
in his or her singularity' (p. 197). Therefore, it requires an introduction of 'sexed rights,' which entail 'a wider context of human liberation' (Irigaray, 2000: p. 11), rather than a support for a homogenous and calculable law.

It seems all the more critical given the crucial role of women in creating the conditions for living in any society or community. As Vandana Shiva points out in her staunch criticism of capitalist economy, which is concerned primarily with growth (this fixation on growth is a perfect example of quantitative uniformity and perversion of democracy denounced by Irigaray) and marginalizes the role of women in the sustenance of living conditions:

Women have been the primary producers in the sustenance economy. They are the providers of food and water, of health, and social security.

"Growth" in the global economy has led to the destruction of nature's economy - through which environmental regeneration takes place. It has also destroyed the people's sustenance economy - within which women work to sustain society. Ironically, this hard, unpaid labor is frequently denied the name of work. (Shiva, 2015: p. 116).

Similarly, Irigaray leaves no doubt about the necessity of overcoming the culture of exploitation, marginalization, and even commodification of women (Irigaray, 1985: pp. 170-197), which is also a culture of disregard for our 'natural belonging' and nature itself. Since human existence, as Irigaray argues in A New Culture of Energy, depends on our ability 'to provide ourselves with a reserve of available breath' (Irigaray, 2021: p. 20), woman's liberation cannot take place without 'faithfulness and attention to her own breathing' (Irigaray, 2004b: p. 166) as the very condition of both her autonomy and the change in human's attitude towards nonhuman living beings and nature in general. That is why Irigaray treats the notions of freedom and air as intrinsically connected. Now, on the one hand, in the cultivation of self-affection, namely, in paying attention to the (both physical and spiritual) practice of breathing, woman can acquire her autonomy. However, on the other, air as such is free; it is indeed a conveyor of freedom since it always remains unbounded by any ontological, theoretical or formal enclosure. Arguing why air should be considered the principal ingredient of life, Irigaray explains that '[n]o other element is as light, as free, and as much in the "fundamental" mode of a permanent, available, "there is", (Irigaray, 1999: p. 8).

Accordingly, in The Age of the Breath, Irigaray announces a new epoch for humanity characterized by harmony between our bonding with nature and devotion to our spiritual evolution, an age of awakening to divinity that takes place 'through a continuous passage from nature to grace' (Irigaray, 2004b: p. 165). It is not surprising that she once again emphasizes the importance of the feminine divine as an injunction to change the world and our role in it: "[i]ndeed the woman's almost natural disposition to the divine does not tolerate the domination over nature, over the world, even arrogance towards them' (Irigaray, 2004b: p. 167). Already in Elemental Passions, we can find the same kind of injunction to pursue 'a new human identity' (Irigaray, 1992: p. 4) through a transformation of our relations with nature and with each other. Naturally, the pursuit 
of divinity (or this new identity) by means of the cultivation of breath has its political implications: firstly, '[...] the breath can function as the middle term between different cultures, and it is also the middle term between singularity and community, an opening, as it were, from which the Irigarayan couple, or any other dialectical relation between persons [...] is formed' (Škof, Holmes, 2013: p. 7); but, as I point out, the divinity that Irigaray is interested in has to have its political weight for it is related to our maturing as (or into) citizens, and as such, it is intrinsically connected to the question of democracy, which of course Irigaray favors as a way of organizing our living together or what she calls our 'gathering together with the other(s)' (Irigaray, 2019: p. 3) in the spirit of the relational autonomy and 'a dwelling more vast, more spacious, or even more generally peaceful' (Irigaray, 1999: p. 8).

Despite the emphasis on man's bonding with nature, the spiritual development, which involves political growth and which Irigaray also describes as 'becoming divine,' has to challenge the threat of resorting to the logic of fusion (Irigaray, 2015: pp. 255, 268), 'unmediated sensibility' (Irigaray, 2000: p. 117), merging into one with nature or with the other. Reduction to nature (or fusion with it) would exclude the possibility of liberation of oneself and transformation of the world. Also, the very possibility of a symbiotic relationship with the other or merging in some kind of homogeneous union would undermine the importance of responsibility we all individually and collectively bear. It is all the more important given the fact that such responsibility is presupposed in Irigaray's idea of respectful and cultivated citizenship. Derrida probably is very close to Irigaray's sentiment when he argues that.

[...] all "living together" that would limit itself to the symbiotic or that would be regulated according to a figure of the symbiotic or the organic is a first lapse of the sense [un manquement au sens] and of the "must" of "living together." Here is, therefore, a double and paradoxical prescription. [...] "Living together" is reducible neither to organic symbiosis nor to the juridicopolitical contract (Derrida, 2013: pp. 26-27).

Irigaray offers a similar approach by questioning any concept of living together that would not stem from singular responsibility and autonomy. Since, in her view, breathing 'corresponds to taking charge of one's life' (Irigaray, 2002: p. 50), she rejects passivity, which she attributes to 'taking air from others' in favor of committing oneself to free and spontaneous breathing. Similarly to the period of our dependency on mother's placenta, which precedes our birth and biological autonomy, this political and ethical passivity consists in clinging to 'socio-cultural placenta that passes on to us an already exhaled, already used, not truly pure air' (74, $c f$. Irigaray, 2017a: p. 42). Thus, if we are not committed to the cultivation of breathing, we risk becoming 'a sort of mass in which each individual has not yet conquered his or her personal life but lives on a collective, social and cultural respiration, on an unconscious breathing of a group, beginning with that of the family' (Irigaray, 2015: p. 254, $c f$. Irigaray, 2000: p. 101). In a similar vein, in a conversation with Maurizio Ferraris, 
Derrida declares that he 'is not of the family' and explains what the risks of immersing into an 'organic totality' might be.

I'm not one of the family means, in general, "I do not define myself on the basis of my belonging to the family", or to civil society, or to the state; I do not define myself on the basis of elementary forms of kinship. But it also means, more figuratively, that I am not part of any group, that I do not identify myself with a linguistic community, a national community, a political party, or with any group or clique whatsoever, with any philosophical or literary school. "I am not one of the family" means: do not consider me "one of you", "don't count me in", I want to keep my freedom, always: this, for me, is the condition not only for being singular and other, but also for entering into relation with the singularity and alterity of others. When someone is one of the family, not only does he lose himself in the herd, but he loses the others as well; the others become simply places, family functions, or places or functions in the organic totality [all emphases mine - A.K.] that constitutes a group, school, nation or community of subjects speaking the same language. (Derrida, Ferraris, 2002: p. 27).

Giving oneself up to natural, familial, or social bonds, to consanguinity or kinship, genealogy, or tradition, which only reinforces the phantasm of unity while completely neglecting our personal desire for emancipation, is actually one of Irigaray's main arguments in To Be Born, where she argues that bonding can never mean blending. This argument can also be aimed at societies where everyone becomes a neutral individual and the sexuate difference is disregarded. Irigaray describes such a society obsessed with reducing alterity to sameness in The Forgetting of Air...: 'Man, wanting to regain possession of himself as constituting and gathering together the whole, apprehends only the nothing: a fabricated airbubble, empty correlate of the whole' (Irigaray, 1999: p. 17). This kind of culture of gathering based on enclosure and domination can only imitate life. In fact, it sucks the air out of life. In The Age of Breath, Irigaray identifies it with the diabolic (as opposed to the pursuit of divinity she advocates) that 'takes away the air from the others, from the world. It suffocates with its sterile repetitions, its presumptuous imitations, with its wishes deprived of respect for life. It also annoys with its insistence, its pretension to dominate everything without being able to remain itself' (Irigaray, 2004b: p. 166).

Now, only a democratic society can become the remedy for the culture of exploitation and domination. However, as urgent as this democratic injunction is, the idea of democratic citizenship remains, just like feminine divinity, an infinite task, for it cannot be enclosed by any teleology or eschatology. This resurrection of the feminine world takes place 'from today onwards' (Irigaray, 2004b: p. 167). Arguing for her project of a new citizenship and civil, democratic society, Irigaray insists that ' $[w]$ e have to work at this task here and now, and change society not only by means of the decision of political personalities, but democratically, starting with our own decisions: in the way we act, speak and exist' (Irigaray, 2000: pp. 119-120). And while an effort to shift '[...] the worldview from one dominated by markets and 
military, monocultures and mechanistic reductionism, to the peaceful cocreation and coevolution of diverse beings, connected through the common bonds of life' (Shiva, 2015: p. 165) is dubbed by Shiva 'Earth Democracy,' Irigaray's political and ethical injunction - which puts the question of breathing at the heart of this kind of democratic transformations and treats it as their condition - might be considered a call for air democracy. However, we should not forget that in this call for political (and spiritual) awakening to nonexclusionary, democratic co-existence the prerequisite is to change the material conditions of women and all the burdened and exploited. As such, it requires deep changes in our social relations, starting with the suffocating system of capitalist economy.

\section{Air Matters}

In Between East and West, Irigaray states that '[w]e speak of elementary needs like the need to eat and to drink, but not of the need to breathe. That corresponds nevertheless to our first and most radical need' (Irigaray, 2002: p. 74). Although it is crucial to address the crises related, for example, to water shortages or water pollution, famine or the quality of food we consume, it is no wonder that Irigaray urges us to pay special attention to air as the very milieu of both biological and spiritual life. We probably would not even be able to address these other issues in a just manner without paying attention to our breath and to air we breathe. Naturally, for Irigaray, the exigency of spiritual growth related to breathing is undeniable, but because air serves as the very opening of the difference between the spiritual and the material domain, the material and biological reality is not neglected in her thought. On the contrary, her thought can offer a shift in perceiving the material conditions for the sustenance of life, of which the right to breathe freely with pure air is the most fundamental consequence.

Her in-depth critique of alienation and aspiration to possess in the Western culture and capitalist societies can be used not only against the economic practice of treating nature as an inexhaustible resource one can exploit free of charge but also against the commodification of the environment (related to the commodification of women $)^{7}$ that inevitably leads to our suffocation. The following passage from The Forgetting of Air... can be treated as a confirmation of this interpretation, just as it also is a strong rebuke of the capitalist logic of growth and accumulation.

Through a monopoly on what would be declared a respirable commodity [valeur respirable], through immobilization of the resources of air, through sublime atmospheric transformation, through rarefaction of ambiance: the most haughty quarreling with each other over ever more ethereal spheres. Rarefaction and compression: the volume of air must remain controllable. Capital-

\footnotetext{
7 'And the succession of different property regimes - slave, feudal, capitalist - has not altered the fact that woman is possessed by the head of the family as a "mere instrument of production" and reproduction' (Irigaray, 1987: p. 121).
} 
ization, thus lack. Purification -thus? - lack and pollution. For ordinary mortals, in any case. (Irigaray, 1999: p. 6). ${ }^{8}$

Therefore, democracies that justify capitalization and commodification have been merely a poor substitute for democracy while 'the democratic ideal has become alienated from itself in a quantitative evaluation arbitrated by money' (Irigaray, 2011: pp. 196-197). That is a reminder of Irigaray's words from The Forgetting of Air... in which she professes the irreducibility of the donation of air to any kind of calculability and economy of exchange by stating: '[t]his debt of life seems natural and like it must remain unpaid. Unpayable' (Irigaray, 1999: p. 28). Accordingly, in A New Culture of Energy, she states that '[m]aintaining my life is a way of giving thanks for the gift received' (Irigaray, 2021: p. 25) and calls for another economy based on sharing with other humans or another logic that does not ' $[\ldots]$ neglect the properties of life and the margin of freedom that a human being has to preserve and cultivate' (Irigaray, 2019: p. 4).

From this point of view, any efforts on the part of neoclassical economists to justify environmental care by turning nature into a commodity (and thus attributing to it a market value) serve the same logic as the forces of exploitation do. John Bellamy Foster addresses this issue in his harsh reproach of capitalist attitude toward the environment: 'It is not so much the failure to internalize large parts of nature into the economy that is the source of environmental problems, but rather that more and more of nature is reduced to mere cash nexus and is not treated in accordance with broader, more ecological principles' (Foster, 2002: pp. 32-33). ${ }^{9}$ Consequently, the market-driven perspective is that any shortcomings with regard to environmental protection stem from the fact that ' $[\ldots]$ the environment has not been fully incorporated within the market economy, and does not operate according to the laws of economic supply and demand' (p. 30). Contrary to that view, democratic blossoming

\footnotetext{
${ }^{8}$ The last sentence of the quoted passage can be interpreted at least in two ways: as a dig at the onto-theological efforts to account for mortal (human) living and as a sharp diagnosis of class division and injustice (concerning access to clean air but also to means for spiritual development). Thus, 'immobilization of the resources of air' could be treated as a cause of the deepening of economic inequality. Furthermore, environmental degradation affects the poor more severely because those in power, the haves, possess the economic means to deal, at least to some extent, with environmental crises ( $c f$. Magdoff, Foster, 2011: pp. 85-86). As Karl Marx puts it: '[a]ccumulation of wealth at one pole is, therefore, at the same time accumulation of misery, the torment of labour, slavery, ignorance, brutalization and moral degradation at the opposite pole, i.e. on the side of the class that produces its own product as capital' (Marx, 1982: p. 799). Irigaray would probably add to this statement that it is actually disregard for breathing that leads to 'any master-slave struggle at an economic level' (Irigaray, 2017b: p. 127). Thus, in my view, the class perspective has to indispensably reverberate in the call for air democracy.

${ }^{9}$ Foster mentions commodification of air as an example (or perhaps, from Irigaray's perspective, an exemplar) of this kind of destructive reductionism: '[...] if clean air is not a marketable good with a price, then the market places no value on it. Thus when an industrial plant emits air pollution, it simply externalizes the cost (which shows up in premature deaths, damage to ecosystems, deterioration of environmental amenities, etc.) to society, while the environmental damage is not internalized within the market or on the balance sheet of the firm. The answer to this, from the standpoint of neoclassical environmental economics, is to create markets in clean air, thereby internalizing such external costs within the market. The overall logic is one of bringing the earth within the balance sheet' (Foster, 2002: 27, $c f$. Dobson, 2007: p. 68).
} 
that Irigaray professes would have to involve a legislative push for fundamental environmental rights and laws that would transgress and defy boundaries of the market-driven economy. ${ }^{10}$ This could be viewed as an important achievement in terms of cultivation of our bonds with each other and nature. Furthermore, it would ensure our greater autonomy as citizens of the world.

This effort has to come out of our meditation on 'the gift of pure air coming from the vegetal world' (Irigaray, 2017b: p. 129) and has to lead to inventiveness and transformation of our language, laws, and social relations: 'We must consider and show with our own language how the vegetal word contributes to the discovery and the accomplishment of us, humans, as living beings coexisting with other, human or nonhuman, beings' (p. 129). The lesson of the vegetal world is to be concerned about our contribution to the environment rather than to its acquisitive exploitation. That is a universal lesson since in breathing we all are the participants of 'a universal exchange,' which, if taken with due attention, leads to a realization that we are 'citizens of the world,' 'inhabitants of the earth' who 'joined in sharing of air' (Irigaray, 2016: p. 22). Moreover, since the universal is not 'an accumulation of possession' (Irigaray, 2000: pp. 28-29) and it 'develops out of you as a flower grows from the earth' (Irigaray, 2000: p. 29), it cannot be unveiled otherwise than through attestation and affirmation of singularity, to wit, all living singularities. Perhaps, for Irigaray, the only way to reconcile singularity and universality means to focus on the sexuate life and the very conditions of its survival, sustenance, and growth. The call for responsibility out of universal respect for life - which for Irigaray is respect for sexuate difference, the irreducibility of singularity, heterogony of sharing requires of us to 'reconsider our sociocultural foundations, especially the language we use to enter into relationships between us, but also with our living environment' (p. 89). Only then can we participate in a 'grateful communion with the whole living world' (p. 93).

Open Access This article is licensed under a Creative Commons Attribution 4.0 International License, which permits use, sharing, adaptation, distribution and reproduction in any medium or format, as long as you give appropriate credit to the original author(s) and the source, provide a link to the Creative Commons licence, and indicate if changes were made. The images or other third party material in this article are included in the article's Creative Commons licence, unless indicated otherwise in a credit line to the material. If material is not included in the article's Creative Commons licence and your intended use is not permitted by statutory regulation or exceeds the permitted use, you will need to obtain permission directly from the copyright holder. To view a copy of this licence, visit http://creativecommons.org/licen ses/by/4.0/.

\footnotetext{
${ }^{10}$ Ian Angus provides an example of such rights. He considers them principal in the ecosocialist program: 'Clean air and water and fertile soil, as well as universal access to chemical-free food and renewable, non-polluting energy sources, are basic human and natural rights defended by ecosocialism. Far from being "despotic," collective policy-making on the local, regional, national, and international levels amounts to society's exercise of communal freedom and responsibility. This freedom of decision constitutes a liberation from the alienating economic "laws" of the growth-oriented capitalist system' (Angus, 2016: pp. 205-206).
} 


\section{References}

Angus, I. (2016). Facing the Anthropocene. Monthly Review Press.

De Vries, R. J. (2008). Sharing air: Becoming two in the spirit. In L. Irigaray \& M. Green (Eds.), Teaching, Luce Irigaray (pp. 142-155). Continuum.

Derrida, J. (1999). Adieu to Emmanuel Levinas. P. A. Brault, M. Naas. Stanford University Press.

Derrida, J. (2002). Faith and knowledge: The two sources of "religion" at the limits of reason alone. Trans. S. Weber. In idem, Acts of religion (pp. 40-101). Routledge.

Derrida, J. (2005). Rogues: Two essays on reason. P. A. Brault, M. Naas. Stanford University Press.

Derrida, J. (2013). Avowing. Trans. G. Anidjar. In E. Weber (Ed.), Living together: Jacques Derrida's communities of violence and peace (pp. 18-41). Fordham University Press.

Derrida, J. (2014). The death penalty (Vol. 1). The University of Chicago Press.

Derrida, J., \& Ferraris, M. (2002). A taste for the secret. Polity Press.

Derrida, J., \& Roudinesco, E. (2004). For what tomorrow... a dialogue. Trans. J. Fort. Stanford University Press.

Dobson, A. (2007). Green political thought (Fourth Edition). Routledge.

Foster, J. B. (2002). Ecology against capitalism. Monthly Review Press.

Irigaray, L. (1985). This sex which is not one. C. Porter, C. Burke. Cornell University Press.

Irigaray, L. (1987). Speculum of the other woman. Cornell University Press.

Irigaray, L. (1992). Elemental passions. Trans. J. Collie, J. Still. Routledge.

Irigaray, L. (1996). I love to you. Routledge.

Irigaray, L. (1999). The forgetting of air in Martin Heidegger. The Athlone Press.

Irigaray, L. (2000). Democracy begins between two. The Athlone Press.

Irigaray, L. (2002). Between east and west. Columbia University Press.

Irigaray, L. (2004a). How can we live together in a lasting way? In idem, Key writings (pp. 123-133). Continuum.

Irigaray, L. (2004b). The age of breath. In idem, Key writings (pp. 165-171). Continuum.

Irigaray, L. (2011). There can be no democracy without a culture of difference. Trans. H. Bostic, L. Irigaray, \& S. Pluháček. In A. Goodbody \& K. Rigby (Eds.), Ecocritical theory: New European approaches (pp. 194-205). University of Virginia Press.

Irigaray, L. (2015). Ethical gestures towards the other. In L. Irigaray \& M. Marder (Eds.), Building a new world Luce Irigaray: Teaching II (pp. 253-271). Palgrave Macmillan.

Irigaray, L. (2016). Luce Irigaray. In L. Irigaray \& M. Marder (Eds.), Through vegetal being. Two philosophical perspectives (pp. 1-107). Columbia University Press.

Irigaray, L. (2017a). To be born. Palgrave Macmillan.

Irigaray, L. (2017b). What the vegetal world says to us. In M. Gagliano, J. C. Ryan, \& P. Vieira (Eds.), The language of plants: Science, philosophy, literature (pp. 126-135). University of Minnesota Press.

Irigaray, L. (2019). Sharing the fire. Palgrave Macmillan.

Irigaray, L. (2021). A new culture of energy. Columbia University Press.

Kopka, A. (2020). Sharing (out) democracy. On the democratic injunction for climate justice. The Polish Journal of Aesthetics, 58(3), 45-68. https://doi.org/10.19205/58.20.4

Magdoff, F., \& Foster, J. B. (2011). What every environmentalist needs to know about capitalism. Monthly Review Press.

Marx, K. (1982). Capital. A critique of political economy (Vol. 1). Trans B Fowkes Penguin Books.

Shiva, V. (2015). Earth democracy. North Atlantic Books.

Škof, L. (2015). Breath of proximity: Intersubjectivity, ethics and peace. Springer.

Škof, L., Holmes, E. A. (2013). Towards breathing with Luce Irigaray. In idem (Eds.), Breathing with Luce Irigaray (pp. 1-11). Bloomsbury.

Szopa, K. (2018). Poetyka rozkwitania. Różnica płciowa w filozofii Luce Irigaray. Instytut Badań Literackich PAN.

Szopa, K. (2019). From desire to be born to desire for being together in the philosophy of Luce Irigaray. In C. Hadjioannou, L. Irigaray, \& M. O’Brien (Eds.), Towards a new human being (pp. 51-69). Palgrave Macmillan.

Publisher's Note Springer Nature remains neutral with regard to jurisdictional claims in published maps and institutional affiliations. 